CATALAN REVIEW

Catalan Review

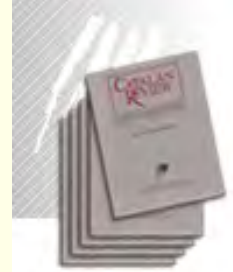

You are accessing the Digital Archive of the Catalan Review Journal.

By accessing and/or using this Digital Archive, you accept and agree to abide by the Terms and Conditions of Use available at http://www.nacs-

catalanstudies.org/catalan review.html

Catalan Review is the premier international scholarly journal devoted to all aspects of Catalan culture. By Catalan culture is understood all manifestations of intellectual and artistic life produced in the Catalan language or in the geographical areas where Catalan is spoken. Catalan Review has been in publication since 1986 .
NORTH

AMERICAN

CATALAN

SOCIETY
Esteu accedint a l'Arxiu Digital del Catalan Review

A l' accedir i / o utilitzar aquest Arxiu Digital, vostè accepta i es compromet a complir els termes i condicions d'ús disponibles a http://www.nacs-

catalanstudies.org/catalan review.html

Catalan Review és la primera revista internacional dedicada a tots els aspectes de la cultura catalana. Per la cultura catalana s'entén totes les manifestacions de la vida intel lectual i artística produïda en llengua catalana o en les zones geogràfiques on es parla català. Catalan Review es publica des de 1986.

\title{
Francesc Eiximenis' Brief Compendium on Medieval Miracles: El Primer del Crestià, Chapters 56-59 David J. Viera
}

Catalan Review, Vol. XVI, number 1-2, (2002), p. 221-228 


\section{FRANCESC EIXIMENIS' BRIEF COMPENDIUM ON MEDIEVAL MIRACLES:}

EL PRIMER DEL CRESTIÀ, CHAPTERS $56-59$

\section{DAVID J. VIERA}

Francesc Eiximenis (1330-1409), a Franciscan, became one of the leading writers of fourteenth-century Iberia. In addition, several scholars have referred to him as the author who wrote the last great encyclopedia, Lo Crestia, which Eiximenis planned to divide into thirteen books in order to bring to his reader's mind Christ and the twelve apostles. Today only four books of this ambitious work survive (books I, II, III, XII), causing some scholars to conclude that he never wrote the remaining volumes.

A detailed search through the bibliography on Eiximenis shows that one neglected area in studies on the friar is his role as hagiographer. Although he wrote no hagiographic work per se, one finds in his fifth book of the Llibre dels àngels much information on St. Michael and, in other treatises, materials on saints' lives.'

Medieval lives of saints are ostensibly tied to miracles, a requisite for canonization. Therefore, Eiximenis followed this practice by uniting the two in his Primer del Crestià, chapters 56-59, in which he cited various types of miracles from early Christianity to his age. His purpose, however, was not to assemble a manual on saints and miracles, such as the Flos sanctorum and the Legenda aurea. Instead he included these and subsequent chapters of the Primer to convince his Christian readers that miracles from Christian sources were inspired by God's will and those attributed to Mohammed of Mecca were of demonic or:gin (chs. 62-70). He also emphasized the distinction between the true miracle, a marvel of nature, and pseudo miracles that are produced by alcherny or, in the case of Mohammed, deceit. In addition, these chapters also have another purpose: he wished to assure his Christian readers that God would continue to bring about miracles to convince them that he is omnipresent and to remind them of his almighty power and mercy: "lo Senyor no ha encara lexada ne lexarà jamès axí sancta crestiandat que dins ella no haja molts e grans miracles" (ch. 57). He added, however, that in his time there were fewer miracles than at the beginning of Christianity.

In this study I specify what Eiximenis defined as a true miracle. I

1 See my forthcoming study, "Francesc Eiximenis, hagiógrafo," in Literatura $y$ Cristiandad [Libro-Homenaje al prof. Jesús Montoya Martínez]. 
also identify the texts and compendia he sought for authentic miracula, his selection of saints and places where miracles occurred, and types of medieval miracles he preferred to include. I limit this study to chapters 56-59 since it is here that Eiximenis discussed the essence of the medieval miracle and its folkloric character. Chapters $60-70$, not included in this study, deal with defining a true Christian miracle and are more erudite and philosophical.

Eiximenis attempted to follow a systematic order in his presentation of miracles. After enticing his Catalan reader in the opening paragraph by referring to miracles of Mary "de Monserrat, del Puig de França, de Valluert e de Ronsesvalls (chs. 56), ${ }^{2}$ Eiximenis presented a spatial order for miracles he detailed: the Far East: India, "Surrarchan" (Sarrancha?)(chs. 56), the Middle East: "Arabia en lo mont de Sinay" (chs. 56-57); and "Babilònia la Nova"(ch. 57); the West: Spain, England, Ireland, and the Kingdom of Aragon (chs, 57-59).4 However, the Franciscan introduced several departures from his proposed route: between the Far and Middle East he stopped off at Apulia ch. 56) near Naples and later found his way back to Italy from Ireland, this time to visit Padua (ch. 57).

Despite Eiximenis' valiant effort to keep his miracles in a geographically ordered form, what appears to govern his arrangement is the sources or text(s) he had before him. His miracles that took place in the Far and Middle East derive from Marco Polo's De regionibus, III, while his information on the miracula of St. Clement, pope and martyr, and Apulia appears to come from the Flos sanctorum and John Bradwardine's De causa Dei contra Pelagium et de virtute causarum (I344), which appears to be the essential source of Eiximenis' chapters. However, he recounted a miracle that occurred in "Babilònia la Nova" based on the description of a fellow Franciscan: "les coses damunt dites hagui de frare nostre qui dix que.y era stat present" (ch. 57) as well as his description of Anthony de Padua's preserved tongue, "que sta axí fresca e vermella e bella segons que $m$ 'an dit (my italics) com lo primer dia que morí" (ch. 57 ).

There are similarities among the diverse miracles that give us an idea about what attracted Eiximenis to his personal selection. The

2 Eiximenis cited a number of miracles of Mary throughout his works (Viera 121-30).

${ }_{3}$ Eiximenis may have consulted a manuscript attributed to March de Venetia (i. e., Marco Polo). At least two printed editions of this work appeared later: S. Grynaeus, Novus orbis, and De regionibus: "Samarcham civitas magna et egregia est in regione illa, tributaria Nepoti magna Cham" (III, P. 33, ch. 39).

${ }_{4}$ Primer, ch. 56: "Primerament parlarem de les Indies [...] aprés passem a Arabia en lo mont de Sinay [...] aprés passem envers ponent [...] [Castile] [...] aprés passem envers tremuntana [England, Ireland] [...] aprés trobaràs en Padua [...]. D aqui passa a

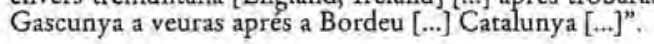


miracles surrounding the tombs of Thomas the Apostle and Clement, and those that took place on St. Michael's feast day in Apulia, describe the displacement of a large volume of water, which recalls the deliverance of the Jews from Egypt. Also in the narrations of Thomas and of Ubaldo, bishop of Gubbio in Umbria, Eiximenis explained that each year at their feast days the faithful would cut the nails and hair of the saint and trim his beard, which, miraculously, kept on growing.'

The healing of the infirm is a prime motif in many of Eiximenis' miracles. Chapters 56-58 contain several examples of holy oils or balsams sometimes issuing from a saint's corpse to heal a diseased believer. Eiximenis begins by recounting the well-known tradition of St. Catherine's tomb at a monastery near Mount Sinai, as well as several tombs of Italy, where Nicholas of Myra and the apostle Bartolomeu cure the faithful at Bari and Benevento, respectively. ${ }^{6}$ Eiximenis twice mentioned a disease called "mal de caure" (epilepsy), of which one believer was cured at the humble chapel of St. Michael near Bordeaux, admitting that information about this miracle came from an oral source. He also recalled his stay in Cologne, where a tradition has it that the three kings who visited the Christ child were believed to be buried (Brewer 340), and informed us that an epileptic seizure will quickly pass if Christians utter the names of the three wise men while they stand over the epileptic. Another disease called "foc de sant Antoni," skin caused by a blood infection, could be cured when the diseased person bathed in wine the corpse of Anthony the Hermit at Vienne, France. $^{8}$

By far the most interesting cures involve a disease called "mal de lop", known in medieval times as "morbus regius" ("the king's evil"). Identified throughout the ages as different diseases (scrofula, strumae,

5 References to Thomas appear in (De regionibus, III, pt. 3, chs. 24, 27, 43, pp. I43$45,147,159)$.

6 The account of the holy oil that issues from Nicholas' tomb is also found in the Legenda Aurea (39).

7 Other names for this disease were "foc de sant Marçal," "foc volant," and "foc salvarge." (Alcover and Moll 5: 936).

8 Eiximenis also mentioned in ch. 57 that a French sant Ment was called upon by Christians to cure a serious leg infection. The reference to "sant Ment" (ch. 57) is clarified in a recent study (Colón Doménech 298-302). Citing a passage from ch. 138 of the Dotzè, "mal de bues de negres plagues apellat de sent Ment qui.ls turmentaran tant e tan longament" Germà Colón analyses the term "sent Ment," he believes to be "mal de sement," which was probably a sin disease, like scabies, or more likely small pox. The derivation of the term is the French "mal de saint Méen." Eiximenis also recalled that Santa Quiteria d'Ayres (Gascony) cured "mal de rảbia" (hydrophobia). His description agrees with that of hagiographers, who depict this martyred daughter of a Galician prince with a dog on a leash. 
leprosy, and jaundice), this illness is caused by abscesses that spread from the throat to the lymph nodes and fester (Barlow 9). Most studies that have dealt with medieval "morbus regius" identify it with scrofula, although its symptoms are much like leprosy (Barlow 10-13; Le Goff 102, 106); Nirenberg 58-59). The miracle cure consisted of the king's royal touch, a practice used from the eleventh century. Scholars affirm that Philip I of France (1060-I108) possessed this power (Bloch $13-14,19,21$ ) and that this custom continued to the reign of Louis IX (Barlow 26).

Eiximenis began his discussion of royal touch affirming that the king of Castile had healing powers: "Lo rey de Castella, posant la mà sobre quartanàrias, feta invocació del nom de Jesu Crist en senyal de la creu, tantost los sana, els guarreix almenys los reys passats ho han hagut, no.m sé s'és del present " (my italics) (ch. 58).

In the last part of the quotation, in which he is unsure if Castilian kings of his day possessed this power, Eiximenis may have engaged in a form of diplomacy as the topic of the king's touch had become politicized. Bear in mind that the Franciscan disliked Peter I, the Cruel (1350-1369), and seemed not to favor the policies of his successors.

Eiximenis then took up John Bradwardine's opus, De causa Dei (39), beginning with the Englishman's words: "Veni in Angliam ad Regem Anglorum praesentem" and translated the Latin that follows almost literally: "lo rey lur posa la mà sobre negú qui haja mal de lop, qui s'apella 'morbus regius,' de continent fet lo senyal de la creu, és guarit" (ch. 57), "At this point Eiximenis ceased translating and began paraphrasing Bradwardine's treatise: "los reys de França solien (my italics) haver aquesta mateixa gràtia de nostre Senyor" (ch. 57). Crucial in this quotation is the word "solien," which is found in the Primer's sole incunabulum. The Latin source reads: "Quod et omnes Reges Christiani Anglorum solent divinitus facere et Francorum, sicut Libri Antiquitatum, et fama Regnorum concors testantur" ( $D e$ causa 39).

Manuscript 1790 of the Primer housed by the Biblioteca Nacional de Madrid contains the word "solen," which further complicates the problem of interpretation: Did Eiximenis believe that French kings of his time, like the English kings, possessed the healing touch of scrofula or did he relegate this sacred gift to the French kings of the past? We must keep in mind his uncertainty concerning healing powers among his contemporary Castilian kings.

Two recent studies have found that Eiximenis held in high regard the French kings of the past, especially Louis IX, but disapproved of

9 A ceremony for healing those diseased with the king's evil existed (Maskell 386-90). 
actions of certain Capetian and Valois regents. ${ }^{10}$ In the Llibre del angels (De sant Miquel 104) he advised the chancellor to abandon the corrupt and sinful court of Philip, probable Philip IV, the Handsome (Dotzé, 2.1:76-77), and had Bishop Stephen inform the French king that he would die without an heir because of his tyranny and nepotism, a reference that I believe is also to Philip IV. Eiximenis was also negative toward Valois kings, especially John II and Charles V, chiding the former for not escaping the Poitiers battlefield before an Anglo-Gascon victory and the latter as a spendthrift who had no regard for his people.

On the other hand, Eiximenis rcgarded some kings (ex. Louis IX and Edward the Confessor) as being saintly and endowed with special gifts (Barlow 11-12, 26; Luard 370-71). But did he deny certain kings saintly attributes (Barlow 17-18) as did William of Malmesbury, whose works Eiximenis may have read while at Oxford? Also, Philippe Buc (144-15) argued that the curative royal touch was an accepted belief of the Parisian school until the thirteenth century, when Capetian ideology "politicized" the belief in the healing touch, and added it to a system that gave credence to several French medieval royal legends beginning with Clovis.

Also in another section of the Primer in which he eulogized France, Eiximenis wrote: "Item special gràcia de Déu atorgat a aquesta casa que guareix mal de porcellanes (the king's evil), segons que m'an dit persones autèntiques qui a hull ho veren de molts qui.n són guarits" (ch. 246).

The use of the present tense here indicates that Eiximenis, a conservative, did not break with traditional thought on the "morbus regius," at least at the beginning of his writing career. The use of the form "solien" in the incunabulum of the Primer may indicate a change based on a fifteenth and sixteenth-century belief that thirteenth and fourteenth-century French kings did not heal scrofula.

The last type of miracles Eiximenis included in these chapters describe modifications in nature, embellished by a sacred power and often related to the life of Jesus or his saints. On Christmas day a unique type of balsam flows that had formed in certain reeds which, when cut with a knife, exude a liquid which helps irrigate the land. Also on this day pennyroyals ("poliol") bloom no matter if the ground is dry. In addition, passages from John the Evangelist, exorcisms, and prayer help against natural disasters. In one of the first

Io See my forthcoming study, "Francesc Eiximenis i els reis de França," in the Actes del XXè Col-loqui de l'Associació Internacional de Llengua i Literatura Caralanes, and "França en les obres de Francesc Eiximenis," in Miscel-lania Giuseppe Tavani also forthcoming. 
miracles Eiximenis described, John the Baptist stabilizes the main column that held up a church dedicated to him in Muslim lands by raising it "tres pams in alt," and in doing so diffused a confrontation between these two religious groups (ch. 56).

Eiximenis also recorded odd changes in living beings that took place in Spain: a mule gives birth in Castile, while in Valencia a child is born with the ability to speak, and another child with hair and a beard resembling that of a thirty-year-old man's. In Arab lands wellknown public figures and other deceased persons are seen walking the streets.

Chapter 58 of the Primer is often cited in modern scudies on Eiximenis because it contains his eulogy of Barcelona. It begins with the notice of St. Francis' stay in Barcelona and contains a fervent praise of St. Eulalia. Eiximenis candidly observed that in Catalonia, excepting Montserrat, there were no miracles nor could he ascribe any to St. Eulalia. In an attempt to cite miracles in his homeland, the Franciscan described two marvels of nature that took place in Canigó, which he concluded were not really miracles. However, in the last part of the chapter Eiximenis gave us a rare glimpse of his writing process. After finishing the Primer, he said that he returned to this chapter to inform us that one of the two marvels of nature he had mentioned in the chapter no longer occurred, that is, throwing a stone into a lake in Canigó would produce a violent wind storm: "despuys que aquest primer libre hagui scrit, entenguí que jatsia que en lo dit stanyse haja sdevengudes coses fort stranyes.; emperò de present res de les damunt dites coses ni s'i sdvenen [...]".

Perhaps this may have been a pretext to recount another miracle Eiximenis believed to be essential to this chapter: his version of the "Santos Corporales" kept at the church of Santo Misterio in Daroca, Zaragoza (Fnciclopedia 1037-38). Tradition has it that several hosts destined for Christian soldiers of the Reconquest were hidden from the invading Moors at a battle near the Castle of Codol, by placing them in a cloth to avoid their profanation. The hosts became live flesh, began to bleed, and remained glued to the cloth. However, Eiximenis' version differs from the traditional legend in the motivation of the hosts' metamorphosis: they became living flesh and attached to the cloth because Christians began to doubt the sacramental nature of the Mass and not because of fear that Muslims would desecrate them.

By way of conclusion I would like to make several observations on the four chapters studied here, which are of special interest to the medievalist, the folklorist, those who study hagiography, and especially those interested in the culture of medieval Catalonia. Eiximenis went to the ends of the earth, as it was known in his time, 
to find true miracles inspired by faith and performed by a divine power. He was very preoccupied and careful in specifying authentic miracles, which were God's way of reminding the faithful of his divine power over all earthly things. True miracles often involve the participation of an intermediary, usually a saint, through whom divine power operates.

Eiximenis preferred miracles involving God's power over nature (ex. rivers), through the saint's presence, including relics, or the Lord's power over the saint (i. e., growing of hair or nails), and nature. Holy oils and balsams formed the sacral sign of miracles. However, several features are absent in the friar's compendium of miracles: the presence of the devil, Christian apparitions, the raising of the dead, beasts, idols, and torture. Therefore the miracles Eiximenis recounted are brief and devoid of demonic figures. It was God's power over nature in the presence of the saintly figure or sacred oils and other liquids that he believed constituted signs of true Christian miracles, which he wished his Catalan readers would recognize as the workings of a divine being.

DAVID J. VIERA TENNESSEE TECH UNIVERSITY

\section{WORKS CITED}

Alcover, Antoni M., and Francesc de B. Moll. Diccionari CatalàValencià-Balear. 1o vols. Palma de Mallorca: Moll, 1930-1962.

BRADWARDINE, John. De causa Dei contra Pelagium et de virtute causarum. Mortonia, 1618.

Brewer, E. Cobham. A Dictionary of Miracles: Imitative, Realistic, and Dogmatic. Detroit: Gale Research, 1966.

BARLOW, Frank. "The King's Evil." English Historical Review 95 (1980) 3-27.

Bloch, Marc. The Royal Touch. Trans. J. E. Anderson. London: Routledge and Kegan Paul, 1973.

Buc, Philippe. "David's Adultery with Bathsheba and the Healing Power of the Capetian Kings." Viator 24 (1993) 10I-20.

COLON DOMÉNECH, Germán. "Filologia y sífilis: sobre el mal de simiente o mal de sement." RFE 78 (1998) 298-304.

"Daroca." Enciclopedia universal ilustrada. Europeo-Americana. Madrid: Espasa Calpe, 1913. 1036-38.

EIximenis, Francesc. De sant Miquel Arcàngel. Ed. Curt J. Wittlin. Barcelona: Curial, 1983. 
- Dotzè llibre del Crestià. Eds. Curt J. Wittlin et al. II:I. Girona: Col-legi Universitari de Girona. Diputació de Girona, 1986.

-. Libre apellat lo primer del Crestià. València: Llambert Palmart, 29 de gener, 1483 .

GRYNAEUS, S. Novus orbis regionum ac insularu veteribus incognitarum. Basel 1534 .

LE GOFF, Jacques. "Le Mal royal au moyen âge: du roi malade au roi guerisseur." Mediaevistik I (1988) 101-09.

LuARD, Henry Richards. Lives of Edward the Confessor. New York: Kraus, 1966.

MASKell, William. Monumenta Ritualia Ecclesiae Anglicanae. Oxford: Clarendon, 1882.

Nirenberg, David. Communities of Violence. Princeton: Princeton UP, 1996.

Polo, Marco. De regionibus orientalibus. III. Cologne, 1671.

VENETUS, Marcus Paulus. De regionibus orientalibus. Cologne: George Schulz, 1671.

VierA, David J. "Els miracles de Maria en l'obra catalana de Francesc Eiximenis." Actes del Quart Col-loqui d'Estudis Catalans a NordAmèrica. Estudis en honor d'Antoni M. Badia i Margarit. Barcelona: Abadia de Montserrat, 1985. I21-30.

VORAGINE, Jacobo de. Jacobi a Voragine Legenda aurea vulgo. Historia lombardica dicta. Ed. T. Graesse. Osnabrück, Otto Zeller, 1969 (rpt). 